\title{
ODSEV GLOBALNIH DRUŽBENIH SPREMEMB NA VSEBINO REGIONALNEGA PROSTORSKEGA PLANIRANJA
}

\author{
Marjan Ravbar ${ }^{*}$ \\ Izvleček \\ UDK $911.3: 71=863$ \\ Ob kratkem pregledu družbenogospodarskih sprememb in razvojnih stopenj regionalnega \\ prostorskega planiranja $v$ Sloveniji po drugi svetovni vojni avtor obravnava metodološka \\ izhodišča pri regionalnem prostorskem planiranju.
}

Ključne besede: Regionalno prostorsko planiranje, Slovenija, prostorska struktura, endogeni razvoj.

\section{REFLECTION OF GLOBAL SOCIAL CHANGES IN THE CONTENTS OF REGIONAL SPATIAL PLANNING}

\section{Abstract}

Following a short overview of socioeconomic changes and developmental stages of regional spatial planning in Slovenia after the $2^{\text {nd }}$ World War, the paper discusses the methodological approaches in regional spatial planning.

Key words: Regional spatial planning; Slovenia; Spatial structure; Endogenous development.

\footnotetext{
* Dr., znanstveni svetnik, Inštitut za geografijo, Trg francoske revolucije 7, SI 1000 Ljubljana, Slovenija
} 


\section{UVOD}

Cilj vseh regionalnih prostorskih planov in strategij regionalnega razvoja je ponuditi poti za izboljšanje življenjskih razmer. Pogoji se s časom spreminjajo, odvisni so od globalnih sprememb v družbi. Slovenija je v povojnem razvoju zaradi modernizacije celotne družbe, deagrarizacije, industrializacije, urbanizacije bistveno spremenila gospodarsko in prebivalstveno strukturo. Prebivalstvo se je $\mathrm{v}$ tem času povečalo za četrtino. Dežela je ob dinamičnem razvoju že v začetku osemdesetih let dosegla raven srednje razvite industrijske države. Delež kmečkega prebivalstva se je zmanjšal na komaj dvajsetino. Od prevlade primarnega sektorja je $\mathrm{v}$ strukturi aktivnega prebivalstva prišlo najprej do prevlade sekundarnega sektorja, posebej $\mathrm{v}$ zadnjih letih pa že prevladuje delež terciarja in kvartarja.

Tabela 1: Delež zaposlenih v Republiki Sloveniji po sektorjih gospodarskih dejavnosti (1953-1996).

\begin{tabular}{|l|r|r|r|r|r|r|}
\hline Sektor gospodarskih dejavnosti & $\begin{array}{c}\text { leto } \\
1953\end{array}$ & $\begin{array}{c}\text { leto } \\
1961\end{array}$ & $\begin{array}{c}\text { leto } \\
1971\end{array}$ & $\begin{array}{c}\text { leto } \\
1981\end{array}$ & $\begin{array}{c}\text { leto } \\
1991\end{array}$ & $\begin{array}{c}\text { leto } \\
1996 *\end{array}$ \\
\hline Primarni sektor & 53,6 & 38,9 & 27,2 & 15,8 & 13,7 & 9,9 \\
\hline Sekundarni sektor & 28,7 & 37,1 & 45,7 & 48,3 & 45,6 & 42,0 \\
\hline Terciarni sektor & 9,5 & 9,8 & 14,8 & 20,5 & 18,4 & 21,3 \\
\hline Kvartarni sektor & 8,2 & 14,2 & 12,3 & 15,4 & 22,3 & 26,7 \\
\hline SKUPAJ & 100,0 & 100,0 & 100,0 & 100,0 & 100,0 & 100,0 \\
\hline
\end{tabular}

* Podatki za leto 1996 so povzeti po Statističnih informacijah, št. 17/97, Statistični urad RS in niso povsem primerljivi s predhodnimi podatki, ki temelje na popisnih rezultatih.

Industrializacija ni povzročila le povečanja materialne proizvodnje in zaposlenosti, marveč ima tudi daljnosežne posledice $v$ degradaciji okolja (Plut, 1987) in v poslabševanju bivalnih razmer. Pod vplivom vseobsežnih družbenih sprememb je prišlo tudi do prostorskih sprememb $v$ poseljenosti. $V$ zgodnji fazi so bile to selitve $s$ podeželja v mesta. Kot povsem nov se je zlasti v sedemdesetih in osemdesetih letih pojavil močan dotok priseljencev iz delov nekdanje skupne države, ki so se najprej začasno, vse pogosteje pa tudi stalno naseljevali. Priseljenci iz nekdanje skupne države predstavljajo desetino stalnega prebivalstva države. Naseljeni so praviloma v mestih s prevladujočo ekstraktivno in/ali delovno intenzivno proizvodnjo. V zadnjem desetletju se je slovensko prebivalstvo pričelo razseljevati iz mest na širša in ožja obmestja, kar pomeni, da je tudi Slovenijo zajel pojav suburbanizacije. (Ravbar, 1995) 


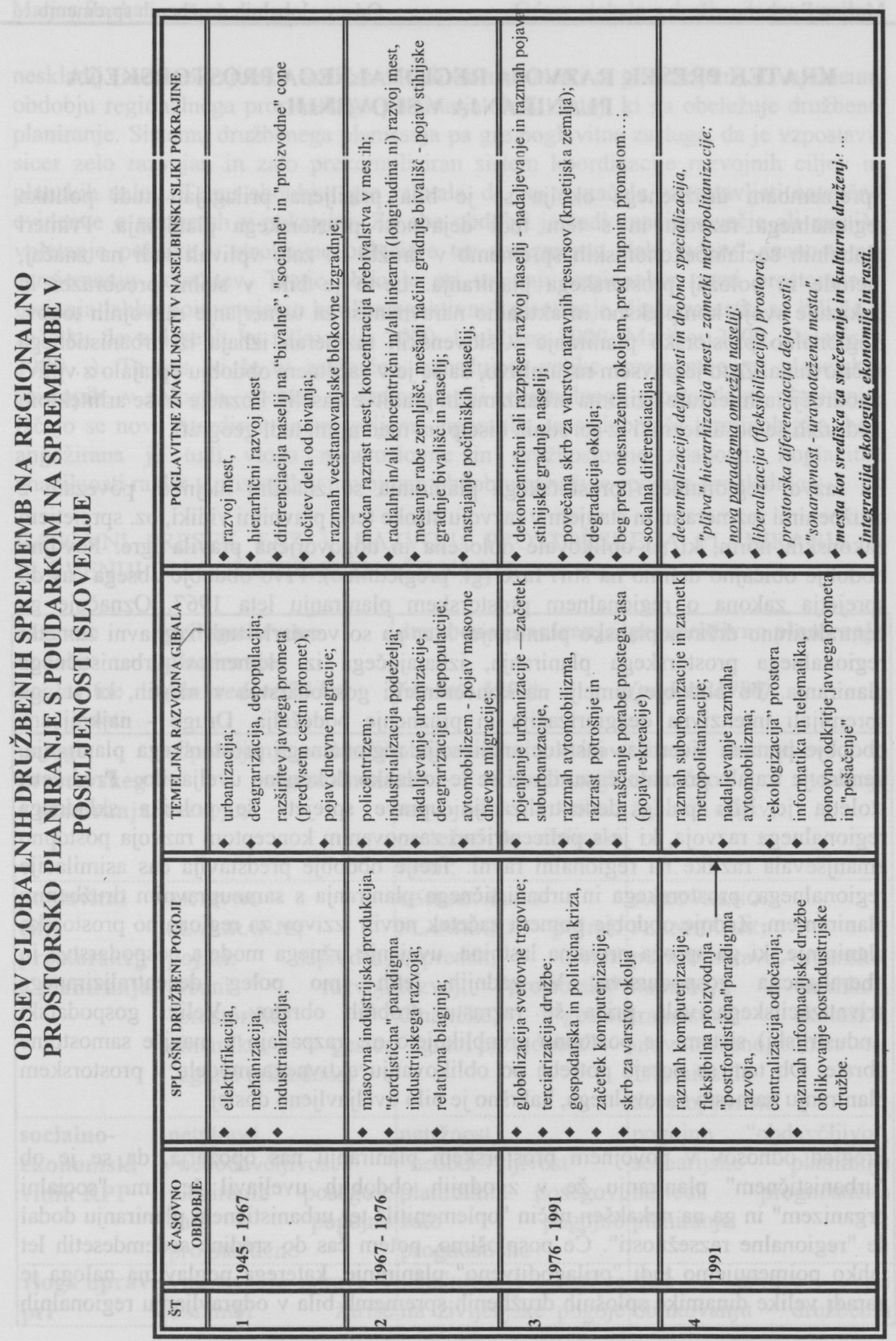




\section{KRATEK PRESEK RAZVOJA REGIONALNEGA PROSTORSKEGA PLANIRANJA V SLOVENIJI}

Spremembam družbenega okolja se je bila prisiljena prilagajati tudi politika regionalnega razvoja in $\mathrm{s}$ tem tudi dejavnost prostorskega planiranja. Primeri globalnih socialnoekonomskih sprememb v družbi so zato vplivali tudi na značaj, metode in položaj prostorskega planiranja. Le-to je bilo $\mathrm{v}$ stalni preobrazbi in dokazuje svojo kompleksno in aktualno naravnanost za usmerjanje razvojnih tokov. Regionalno prostorsko planiranje $\mathrm{v}$ slovenskih razmerah izhaja iz urbanističnega načrtovanja. Zato je povsem razumljivo, da se je $v$ začetnem obdobju oplajalo z vplivi s področja arhitekture oziroma urbanizma in graditve naselij. Pozneje so se arhitektom pridružili še posamezniki iz sorodnih disciplin, med njimi tudi geografi.

Za razvoj regionalnega prostorskega planiranja so značilni mejniki, povezani z družbenimi razmerami in stanjem $v$ razvoju stroke ter s pravnimi vidiki, oz. sprejetjem zakonskih norm, ki so oblikovale določena in dogovorjena pravila igre. Povojno obdobje običajno delimo na štiri faze (gl. preglednico). Prvo obdobje obsega čas do sprejetja zakona o regionalnem prostorskem planiranju leta 1967. Označuje ga centralizirano državnoplansko planiranje, kjer pa so vendarle tudi zaznavni zametki regionalnega prostorskega planiranja, izhajajočega iz elementov urbanističnega planiranja. To obdobje temelji na koncentraciji gospodarstva $\mathrm{v}$ mestih, ki sta ga spremljali intenzivna deagrarizacija in praznenje podeželja. Drugo - najkrajše obdobje pomeni sicer čas institucionalizacije regionalnega prostorskega planiranja, vendar je trajalo premalo časa, da bi se le-to lahko dokončno uveljavilo. Pred četrt stoletja je bila poleg decentralizacije uprave sprejeta še politika skladnega regionalnega razvoja, ki je s policentrično zasnovanim konceptom razvoja postopno zmanjševala razlike na regionalni ravni. Tretje obdobje predstavlja čas asimilacije regionalnega, prostorskega in urbanističnega planiranja s samoupravnim družbenim planiranjem. Zadnje obdobje pomeni začetek novih izzivov za regionalno prostorsko planiranje, ki ga sproža privatna lastnina, uvajanje tržnega modela gospodarstva in liberalizacija gospodarstva. V zadnjih letih smo poleg decentraliziranega privatizacijskega vala priča .še razrastu drobnih obratov. Veliki gospodarski (industrijski) sistemi se postopno preoblikujejo oz. razpadajo $\mathrm{v}$ manjše samostojne obrate. Ob tem se poraja potreba po oblikovanju aktivnega modela $v$ prostorskem planiranju namesto varovalnega, kakršno je bilo uveljavljeno doslej.

Pregled odnosov v povojnem prostorskem planiranju nas opozarja, da se je ob "urbanističnem" planiranju že v zgodnjih obdobjih uveljavil še tim. "socialni organizem" in ga na nekakšen način "oplemenitil" ter urbanističnem planiranju dodal še "regionalne razsežnosti". Če posplošimo, potem čas do sredine sedemdesetih let lahko poimenujemo tudi "prilagoditveno" planiranje, katerega poglavitna naloga je zaradi velike dinamike splošnih družbenih sprememb bila v odpravljanju regionalnih 
neskladij (med pokrajinsko različnimi deli in med mesti in podeželjem). Uvajalnemu obdobju regionalnega prostorskega planiranja sledi zastoj, ki ga obeležuje družbeno planiranje. Sistemu družbenega planiranja pa gre poglavitna zasluga, da je vzpostavil sicer zelo razvejan in zato prekompliciran sistem koordinacije razvojnih ciljev in planskih nalog. Temu obdobju gre zahvala, da so se začele vzpostavljati natančne evidence o razmerah $v$ pokrajini. Za obe obdobji je tudi značilno večje ali manjše vpletanje politike $v$ strokovne odločitve ter sorazmerno slab "odziv" znanosti pri sprejemanju odločitev. Tretje obdobje pri urejanju regionalne ravni prostorskega urejanja lahko poimenujemo kot "perspektivno" planiranje, čigar zametki so bili že v začetku devetdesetih let (Slovenija 2000, Ljubljana 2000, Maribor 2000, Dolenjska $2000 \ldots)$. Ta čas, ki še ni zaključen, označujejo velike spremembe pri planerskih pristopih, $v$ nalogah, vsebini in metodologiji regionalnega prostorskega planiranja. Iščejo se novi interdisciplinarni prijemi, uporablja se sodobnejša terminologija, bolj angažirana je tudi vloga naravoslovne in družboslovne znanosti. Poglavitne značilnosti razlik $v$ pristopih $\mathrm{v}$ povojnem obdobju označuje spodnja preglednica:

\section{ČASOVNI PRESEK FAZ V RAZVOJU PROSTORSKEGA PLANIRANJA V SLOVENIJI IN POGLAVITNE ZNAČILNOSTI}

\begin{tabular}{|c|c|c|c|}
\hline $\begin{array}{l}\text { časovno } \\
\text { obdobje } \\
\text { poglavitne } \\
\text { značilnosti }\end{array}$ & $\begin{array}{l}\text { prilagoditveno } \\
\text { planiranje } \\
\text { (do sredine } 70 \text { let) }\end{array}$ & $\begin{array}{l}\text { družbeno planiranje } \\
\text { (do leta 1990) }\end{array}$ & $\begin{array}{l}\text { perspektivno planiranje } \\
\text { (po letu 1990) }\end{array}$ \\
\hline $\begin{array}{l:}\text { naloge } \\
\text { prostorskeg } \\
\text { a planiranja }\end{array}$ & $\begin{array}{l}\text { odpravljanje neskladij } \\
\mathrm{v} \quad \text { regionalnem } \\
\text { razvoju; }\end{array}$ & $\begin{array}{l}\text { oblikovanje } \text { okvirov } \\
\text { za } \\
\text { razvojnih } \\
\text { pretežno na občinskinacijo } \\
\text { ravni; }\end{array}$ & $\begin{array}{lll}\text { izbor postopkov in } \\
\text { natančno } & \text { tehtanje } \\
\text { željenih ciljev; } & \end{array}$ \\
\hline $\begin{array}{l}\text { poglavitni } \\
\text { cilji } \\
\text { prostorskeg } \\
\text { a planiranja }\end{array}$ & $\begin{array}{l}\text { AKTIVNO } \\
\text { PLANIRANJE; } \\
\text { pojmi: napredek, } \\
\text { urbani } \\
\text { "prostorska" razvoj, } \\
\text { dinamika, geslo: } \\
\text { "zgrabi prihodnost" }\end{array}$ & $\begin{array}{l}\text { OMEJEVALNO } \\
\text { PLANIRANJE pojmi: } \\
\text { napredek, urban } \\
\text { razvoj, "prostorska" } \\
\text { dinamika, geslo: } \\
\text { "zgrabi prihodnost" }\end{array}$ & $\begin{array}{l}\text { VAROVALNO } \\
\text { PLANIRANJE; } \\
\text { pojmi: zdravo, organsko, } \\
\text { humano, "mehko", } \\
\text { trajnostno, ekološko, } \\
\text { uravnoteženo, sonaravno, } \\
\text { "sustainable } \\
\text { developement" }\end{array}$ \\
\hline $\begin{array}{l}\text { socialno- } \\
\text { ekonomski } \\
\text { vidik RPP }\end{array}$ & $\begin{array}{l}\text { netržnost, } \\
\text { "neobdacčljivost" } \\
\text { planiranih posegov, } \\
\text { zato pogojno } \\
\text { prognostično }\end{array}$ & $\begin{array}{l}\text { netržnost, } \\
\text { "neobdavčljivost" } \\
\text { planiranih posegov, } \\
\text { zato pogojno } \\
\text { prognostično }\end{array}$ & $\begin{array}{lr}\text { pogojno } & \text { "obdavčljivo", } \\
\text { scenarijsko } & \text { planiranje } \\
\text { nasledi } & \text { prognostično } \\
\text { planiranje } & \end{array}$ \\
\hline log & $\begin{array}{l}\text { vmešavanje uprave } \\
\text { obrambi }\end{array}$ & $\begin{array}{l}\text { učinkovanje } \\
\text { na življenjske } \mathrm{p}\end{array}$ & $\begin{array}{l}\text { skrb uprave pri } \\
\text { oblikovanju družbenih }\end{array}$ \\
\hline
\end{tabular}




\begin{tabular}{|c|c|c|c|}
\hline nihu & & pr & $\begin{array}{l}\text { pogojev, } \\
\text { "urbani menagement" s } \\
\text { primesjo "dnevne } \\
\text { politike" }\end{array}$ \\
\hline $\begin{array}{l}\text { rodja- } \\
\text { istvo } \\
\text { laniranja }\end{array}$ & $\begin{array}{l}\text { oblikovanje pravnega } \\
\text { sistema javnosti v } \\
\text { prostorskem } \\
\text { planiranju; } \\
\text { eksperti za "tehnična } \\
\text { in umetnostna" } \\
\text { področja; } \\
\text { sektorsko - ciljni } \\
\text { pristop. }\end{array}$ & $\begin{array}{l}\text { strokovno kompetentn } \\
\text { vloga ekspertov - oblik } \\
\text { osredotočenje na rešev } \\
\text { oblikovanje instrument } \\
\text { planiranje na podla } \\
\text { informacijskih sisten } \\
\text { enotni kazalci, "GIS".. } \\
\text { "public private partners }\end{array}$ & $\begin{array}{l}\text { v (npr. davki); } \\
\text { i enotnih prostorsk } \\
\text { v (planski elemen }\end{array}$ \\
\hline $\begin{array}{l}\text { Razmerje } \\
\text { RPP do } \\
\text { politike }\end{array}$ & $\begin{array}{l}\text { poli } \\
\text { pro } \\
\text { plar }\end{array}$ & nost" & niška \\
\hline $\begin{array}{l}\text { razmerje } \\
\text { RPP } \\
\text { znanosti }\end{array}$ & "posamezni" stiki & $\begin{array}{ll}\text { pomoč } & \text { znanstvenih } \\
\text { dognanj } & \end{array}$ & niška \\
\hline
\end{tabular}

\section{METODOLOŠKA IZHODIŠČA PRI REGIONALNEM PROSTORSKEM PLANIRANJU}

Vsebina, oblika in poglavitni elementi regionalnega prostorskega plana se tudi $\mathrm{v}$ deželah $\mathrm{z}$ daljšo regionalnoplansko tradicijo $\mathrm{v}$ zadnjem desetletju spreminjajo in dopolnjujejo tako zaradi splošnopolitičnih izhodišč v družbi, kot tudi zaradi dinamičnega postindustrijskega razvoja in novih metodoloških prijemov, povezanih $\mathrm{s}$ potrebami in spreminjajočimi se zahtevami znotraj samega prostorskega planiranja. Nezanemarljiva je tudi ugotovitev, da se odnos družbe, politike ali uprave do regionalnega prostorskega planiranja spreminja nekako $\mathrm{v}$ valovih (od popolnoma odklonilnega odnosa do absolutne podpore prostorskemu planiranju). Obdobna nihanja politične (ne)naklonjenosti do prostorskega planiranja imajo svoj odsev tudi v slovenskem okolju, še posebej do regionalnega prostorskega planiranja, ki kljub nekajkratnim poskusom še vedno ni zaživelo, še manj pa da bi bilo ustrezno regulirano $\mathrm{s}$ predpisi. Vsebina regionalnega prostorskega planiranja je tako podzavestno odsev širokih družbenih dogajanj.

Klasične politike regionalnega razvoja, ki so jih uvajali $v$ sedemdesetih letih so težile predvsem k oblikovanju različnih ekonomskih."kompenzacijskih" mehanizmov na področju socialne politike in izenačevanja načinov življenja. Vsebovale so tudi 
prostorsko relevantne elemente (npr. investicije $\mathrm{v}$ prometno in komunalno infrastrukturo, agrarna politika). Pri določanju vsebin v regionalnem prostorskem planiranju so kmalu poleg funkcij v omrežju naselij in namenske rabe površin ter demografskih in ekonomskih indikatorjev razvoja pričeli uporabljati še kazalce razvitosti družbenega standarda in kazalce infrastrukturne opremljenosti, ipd. $\mathrm{Na}$ poselitvenem področju je bila sprejeta politika policentričnega regionalnega razvoja, čigar postulat naj bi bila "uravnotežena prostorska distribucija prebivalstva, poseljenosti in ekonomske moči v predhodno dogovorjenih regijah".

V sodobni paradigmi prostorskega in regionalnega razvoja potekata sočasno dva nasprotujoča si procesa: "globalizacija" kot odraz mednarodne prepletenosti gospodarskih in političnih tokov, nasproti "drobnim" lokalnim in/ali regionalno političnim interesom, čigar cilji temelje na uravnoteženem ali samonosilnem regionalnem razvoju, lokalnih ekonömijah, uravnoteženem krogotoku produkcije in surovin ter povezanosti (lokalnega) regionalnega omrežja v enotno mrežo središč.

$\mathrm{Na}$ vsebino regionalnega prostorskega planiranja vpliva tudi politika regionalnega razvoja. Gospodarski razvoj regije pomeni "ne le kvantitativno rast bruto socialnega proizvoda, marveč nanj vplivajo tudi strukturne spremembe $\mathrm{v}$ gospodarjenju in spremembe $v$ načinu življenja (Walter, 1983). Tradicionalni instrumentarij regionalne politike se je -razen v obdobju visoke konjunkture (1970-80) - pokazal kot nezadosten. Deloma tudi zato, ker ni bilo potrebne koordinacije med ukrepi regionalne in drugih politik (industrijska, kmetijska, zaposlitvena ...), deloma pa zato, ker je regionalna politika premalo upoštevala razlike med naravnimi pogoji pokrajin in neekonomskih faktorjev (socialnih, demografskih, izobrazbenih, podjetniških). Sodobne regionalne politike zahtevajo homogenizacijo pokrajine, ki so posledica upoštevanja osrednjih problemov regije, izgube prostih površin in upoštevanja interesov avtohtonega prebivalstva... Primerno regionalno politiko je možno doseči s pomočjo avtonomije finančnih odločitev na regionalni ravni. Na socialnoekonomśkem področju igra odločujočo vlogo kvalifikacijska in izobrazbena struktura, s katero se povečujejo možnosti vključevanja v inovacijske gospodarske tokove, kajti "od znotraj" določena regionalna identiteta in sociokulturna kreativnost so brez dvoma najmočnejši argumenti za vsebinsko (pre)oblikovanje regionalnega prostorskega planiranja. Z ustrezno izobrazbeno strukturo prebivalstva se oblikuje ustvarjalno okolje, ki praviloma tvori prostorsko zaključeno skupnost, pri čemer so administrativne meje manj pomembne oz. ne predstavljajo nekega posebnega "razpoznavnega" kriterija, marveč so to homogenost v načinu ravnanja in zmožnost prilagajanja. Pregled poglavitnih razlik $\mathrm{v}$ pristopih razreševanja vsebinskih regionalnih problemov na globalni ravni prikazuje spodnja preglednica: 
POGLAVITNE RAZLIKE MED KLASIČNIMI IN SODOBNIMI PRISTOPI V REGIONALNEM PROSTORSKEM PLANIRANJU*

\begin{tabular}{|c|c|c|}
\hline $\begin{array}{c}\text { klasična regionalna politika: } \\
=\text { nudenje pomoči na podlagi klasičnih } \\
\text { produkcijskih in lokacijskih faktorjev }\end{array}$ & $\begin{aligned} & \text { inovativna regionalna } \\
& \quad \text { politika: } \\
&= \text { socialno in kulturno } \\
& \text { okolje } \\
&= \text { oblikovanje (med) } \\
& \text { regionalnih omrežij }\end{aligned}$ & $\begin{array}{l}\text { ustvarjalno } \\
\text { okolje }\end{array}$ \\
\hline $\begin{array}{l}\text { - } \quad \text { prometna in energetska infrastruktura; } \\
\text { - } \quad \text { komunikacijska infrastruktura; } \\
\text { - } \quad \text { izobraževalna in zdravstvena infrastruktura; } \\
\text { ponudba površin za industrijo in obrt; } \\
\text { itd. }\end{array}$ & \multicolumn{2}{|c|}{$\begin{array}{l}\text { - } \quad \text { tehnološki transfer (izmenjava informacij); } \\
\text { - } \quad \text { podjetniško svetovanje; } \\
\text { - } \quad \text { mobilnost delovne sile; } \\
\text { - } \quad \text { opremaljeno identiteta; } \\
\text { (sponzorstvo); } \\
\text { visoki potenciali za rekreacijo in prosti } \\
\text { čas; } \\
\text { - } \quad \text { različne socialne aktivnosti; } \\
\text { visoka stopnja neonesnaženosti okolja; } \\
\text { visoko postavljeni standardi kvalitete } \\
\text { življenja; } \\
\text { kultura upravljanja. }\end{array}$} \\
\hline
\end{tabular}

* prirejeno po Roesch (1996)

Klasične raziskave, ki so doslej opozarjale na pomen regionalne opremljenosti in prikazovale gospodarsko strukturo, ponudbo storitvenih dejavnosti, prisotnost visokoproduktivnih raziskovalnih dejavnosti (venture capital), prometno povezanost, kvaliteto življenjskega okolja, itd. nadomeščajo novi pogledi vrednotenja odnosov znotraj regionalne skupnosti. Za to se $\mathrm{v}$ številnih razpravah uporablja pojem ustvarjalno okolje ${ }^{1}$, ki je sinonim za intenzivno povezovanje znanstveno - tehnoloških centrov z ostalimi gospodarskimi omrežji in ima pomembne prostorske učinke na regionalni ravni. Po svoje je to nov pogled in temu je prilagojena svojstvena, vendar sodobna interpretacija vsebin regionalnega planiranja.

Geografija že dolgo povezuje gospodarski prostor z življenjskim prostorom, kajti gospodarski razvoj hkrati pomeni tudi način življenja, bivalno kulturo, prosti čas in infrastrukturo kar vse ima nesporne vplive na pokrajino, na regionalni razvoj in na urejanje prostora. Geografske raziskave lahko $\mathrm{z}$ regionalnimi znanji ter $\mathrm{s}$

${ }^{1}$ podrobnosti glej tudi v naslednjih prispevkih: Aydalot, P. (1986), Nijkamp, P., - Mouwen, A. (1987), Campagni, R., (1991), Maillat, D., (1992), Fromhold-Eisebith, M. (1995). 
socialnogeografsko in strukturno analizo, $\mathrm{z}$ analizo naravnih in ustvarjenih potencialov pokrajine in še posebej prepletanj med njimi, podajo objektivno informacijo, $\mathrm{z}$ analizo zaznavanja problemov pa subjektivno stanje. Med ukrepi "od zgoraj" in človeškimi, lokalnimi, oziroma podjetniškimi aktivnostmi "od spodaj" običajno pogrešamo soočenje in vrednotenje idej in ekonomsko socialnih ukrepov na regionalni ravni politično-administrativnih enot. Zato je pri tej tim. "diagnostični" metodi proučevanja regionalnih problemov $\mathrm{v}$ pokrajini posebej priporočljivo proučevanje tudi prostorsko relevantne mreže podjetniških povezav. (glej spodnji model).

\section{MOŽNI VSEBINSKI MODEL REGIONALNE ANALIZE *}

\begin{tabular}{|c|c|c|c|c|}
\hline & $\begin{array}{l}\text { Cilji /inter } \\
\text { država }\end{array}$ & $\begin{array}{l}\text { esi: } \\
\text { regija } \\
\text { regija }\end{array}$ & $\begin{array}{l}\text { socialnogeografska } \\
\text { analiza kot npr.: }\end{array}$ & $\begin{array}{c}\text { gospodarsko } \\
\text { (marketinška) }^{2} \\
\text { naravnana analiza }^{2}\end{array}$ \\
\hline "od zgoraj" & $\begin{array}{r}\text { Država }= \\
\vdots\end{array}$ & $\begin{array}{l}=L_{1,2,3}, \\
\text { upnosti }\end{array}$ & $\begin{array}{l}\text { strukturna analiza } \\
\text { spremembevstrukturi } \\
\text { prebivalstva } \\
\text { spremembevgospodkrski } \\
\text { struktur } \\
\text { spremanbepolitiǒnihpogojic } \\
\text { regionalna znanja } \\
\text { historična analiza } \\
\text { analiza potencialov }{ }^{4} \\
\text { pokrajinska slika }\end{array}$ & $\begin{array}{l}\text { informacije } \\
\text { institucije } \\
\text { regulacije - ukrepi }{ }^{3} \\
\text { uprava } \\
\text { politični programi } \\
\text { mobilnost: } \\
\text { pretok ljudi, kapitala, blaga in } \\
\text { znanja (idej) } \\
\text { organiziranost } \\
\text { formalna/neformalna: } \\
\text { različna združenja } \\
\text { kooperacijske oblike }\end{array}$ \\
\hline
\end{tabular}

* prirejeno po Maier (1995)

2 gospodarskogeografska analiza predstavlja pripravo kvalitativnih ukrepov, med njimi zlasti medpodjetniško koordinacijo pri oblikovanju skupne strategije, ukrepe za pospeševanje okolju prijaznih oblik gospodarjenja (npr: s subvencijami), ukrepe za pospeševanje infrastrukture, itn.

3 Oblikovanje planerskih in tržnih ukrepov za usmerjanje razvoja gospodarskih aktivnosti ter odpravljanje oz. minimiziranje prostorskih, ekoloških in socialnih navzkrižij. Razvijanje in preizkus metod (modelov) medsebojnega učinkovanja.

4 Oceniti razvojne socialno-ekonomske potenciale ter potencialne potrebe po dodatnih površinah za njihove naprave, hkrati z obremenitvami, ki jih inducirajo npr: posamezne oblike gospodarskih aktivnosti na okolje. Opredeliti konkurenčna razmerja med posameznimi in/ali nasprotujočimi se gospodarskimi aktivnostmi.

5 Pripravo kataloga možnih ukrepov je moč uporabiti za predlog ukrepov na podlagi interdisplinarnih teamskih posvetovanj. 
Slovenija se je na svetovnih konferencah v Riu (1992), Kairu (1995) in Carigradu (1996) obvezala, da bo gospodarski, prebivalstveni in naselbinski razvoj odgovorno snovala v okvirih nosilnih sposobnosti okolja. Sprejeta strategija gospodarskega razvoja Slovenije (1995) postavlja kot enega izmed ključnih ciljev trajno obstojnost gospodarskega razvoja s prostorskega, okoljskega, regionalnega in nacionalnokulturnega razvoja. Skrb za uravnovešen prostorski in za sonaraven gospodarski razvoj sta torej pomembni strateški opredelitvi države, skladen regionalni razvoj z ohranjanjem poglavitnih značilnosti poselitvenega in pokrajinskega vzorca ter ustvarjanje približno enakih pogojev za življenje $v$ vseh slovenskih pokrajinah pa eden poglavitnih strateških ciljev razvoja.

V sodobnem planiranju regionalnega razvoja so najpomembnejši elementi povezani $\mathrm{s}$ socialno-gospodarskimi ukrepi in ekološkimi razsežnostmi. $\mathrm{O}$ endogenem, uravnoteženem, sonaravnem ali samonosilnem regionalnem razvoju je bilo $\mathrm{v}$ zadnjih letih že veliko napisanega ter je pojem eden od pomembnih, morda tudi modnih izrazov in predmet številnih razprav o vlogi regionalnih faktorjev. Nemalokrat se uporablja tudi kot "razvoj od znotraj" za različne, prostorsko zaokrožene prostorske enote, ki so izpostavljene bodisi ekološkim rizikom, bodisi so zaradi različnih družbenih, prevsem strukturnih problemov, drugače ogrožene.

Med različnimi izhodišči, ki utemeljujejo paradigmo endogenega regionalnega razvoja so vsaj trije. Najprej gre za vsebinsko naravnanost k proučitvi regionalnih virov. Drug pomemben element regionalne politike izhaja iz prostorske selektivnosti učinkov urbanega razvoja in hierarhije naselij. Tretji razlog pa je povezan s pojmom skladnega in policentrično zasnovanega regionalnega razvoja. Poleg tega gre še za odločujoče spremembe $\mathrm{v}$ svetovnih ekonomskih dogajanjih, ki so učinkovitost tradicionalnih instrumentarijev regionalne politike močno zmanjšale. Vpliv mednarodnih strukturnih sprememb in regionalne krize so postale tolikšne, da se je vpliv tradicionalnih (ekonomskih) ukrepov regionalne politike zmanjšal predvsem zato, ker inovativno in $\mathrm{v}$ informacijsko družbo usmerjeno gospodarstvo zahteva mobilizacijo človeških potencialov in usmeritve $v$ kapitalsko mnogo bolj naravnane strategije. Ta sredstva pa se običajno kanalizirajo $\mathrm{v}$ območjih $\mathrm{z}$ dinamičnim razvojem.

Opredelitev, poznavanje in pomen regionalnih virov kot razvojnih potencialov z okoljsko (omejitveno) možnostjo rabe neobnovljivih in/ali obnovljivih naravnih virov, kvalitete okolja, prebivalstvenih potencialov, itn. so ključno vsebinsko izhodišče za razglabljanja o vsebini regionalnega prostorskega planiranja. Od njihove opredelitve je odvisna optimalna raba prostora, ki temelji na pravični porazdelitvi dobrin in podpiranju ali omejevanju rabe (ne)obnovljivih regionalnih virov. Oblikovanje kriterijev in težavnost pretvorbe nastajajočega koncepta regionalnega prostorskega planiranja $\mathrm{v}$ uporabne postopke ter upravljalske strategije zahtevajo celovito metodološko in vsebinsko opredelitev problematike, kar $\mathrm{z}$ drugimi besedami pomeni konkretizacijo vsebin na prostorsko-ekološkem, socialno-demografskem ter kulturnem 
in politično-upravnem področju. $\mathrm{Ob}$ tem se postavlja zlasti vprašanje (ne)univerzalnosti posameznih socialno-ekonomskih razvojnih kazalcev in kazalcev rabe posameznih regionalnih virov, zlasti $\mathrm{z}$ vidika primerjav geografsko in razvojno zelo različnih območij (glej model).

Vsebina regionalnega prostorskega planiranja se osredotoča na tiste dobrine skupnega in splošnega pomena, ki so nepogrešljive za razvoj regije kot celote. Zato je cilj regionalnega prostorskega planiranja $\mathrm{v}$ opredelitvi načel za bodoče ureditve $\mathrm{v}$ pokrajini. Določitev smotrne in uravnotežene rabe površin (dobrin) pa poglavitni vsebinski element regionalnega prostorskega plana. Na tej podlagi temelji oblikovanje prostorsko relevantnih usmeritev za gospodarske in negospodarske dejavnosti in tudi strategija poselitvenih struktur na regionalni ravni.

Okvirne vsebinske elemente sestavljajo naslednji sklopi:

\section{(A) poselitvene (naselbinske) strukture; \\ (B) raba prostora ter \\ (C) lokacije in trase (poteki) za infrastrukturo.}

(A) Prostorske ir poselitvene strukture določajo območja, ki jih označujejo različne naselbinske oblike ${ }^{6}$. Med naselbinskimi območji imajo poseben pomen centralna naselja in razvojne naselbinske osi kot posebna ureditvena območja, katerih poglavitni namen je $v$ optimalni ureditvi "svežnja" infrastrukturnih naprav ter prijaznemu usmerjanju stanovanjskih območij in delovnih mest. Pri tem je kljub spremenjeni vlogi naselij še vedno pomenljiva delitev med funkcijami naselij na temeljno, srednjo in višjo raven oskrbe. Za razumevanje in urejanje naselbinske problematike so v obmestjih in na podeželju potrebna tudi spoznanja na regionalni ravni, ki so posledica:

$6 \mathrm{~S}$ pojmom "poselitev" označujemo razmestitev naselij, tako $\mathrm{v}$ funkcijskem kot oblikovnem smislu. Znano je, da naselja niso brez reda ali po naključju razmeščena $\mathrm{v}$ pokrajini. Podlaga temu je njihova gospodarska usmerjenost in obseg funkcij, ki jih opravljajo za prebivalce naselja samega in bližnje okolice, tako imenovanega gravitacijskega zaledja. Razmestitev naselij v pokrajini in poselitveni vzorec, ki ob tem nastaja, določajo še naravne razmere, kulturni milje in družbeno-ekonomski elementi. Hkrati je razmestitev naselij tudi pomemben oblikotvorni element pokrajine. Posledica poselitvenih razmer, gospodarske usmerjenosti in družbenogospodarskih procesov je nastajanje treh območij, kjer se naselja razlikujejo po gospodarskih dejavnostih, morfologiji in videzu. Gre za: mesta, obmestja in podeželska naselja (Ravbar, 1995). 
METODOLOŠKA IZHODIŠČA PRI REGIONALNEM PROSTORSKEM PLANIRANJU

\section{TEMELJNI POJMI IN NAČELA:}

- Sonaravnost: Endogeni oz. uravnotežen razvoj, varstvo narave, regionalni viri, varstvo okolja...

- Poselitev: Omrežje urbanih središč, mestne aglomeracije, razvojne osi, podeželje, stanovanjsko gospodarstvo, infrastrukturno omrežje...

- Skladnost regionalnega razvoja: Gospodarski, socialni in kulturni razvoj, družbena (personalna), gospodarska (tehnična) in institucionalna infrastruktura...

\section{KONCEPT PLANIRANJA NA REGIONALNI RAVNI}

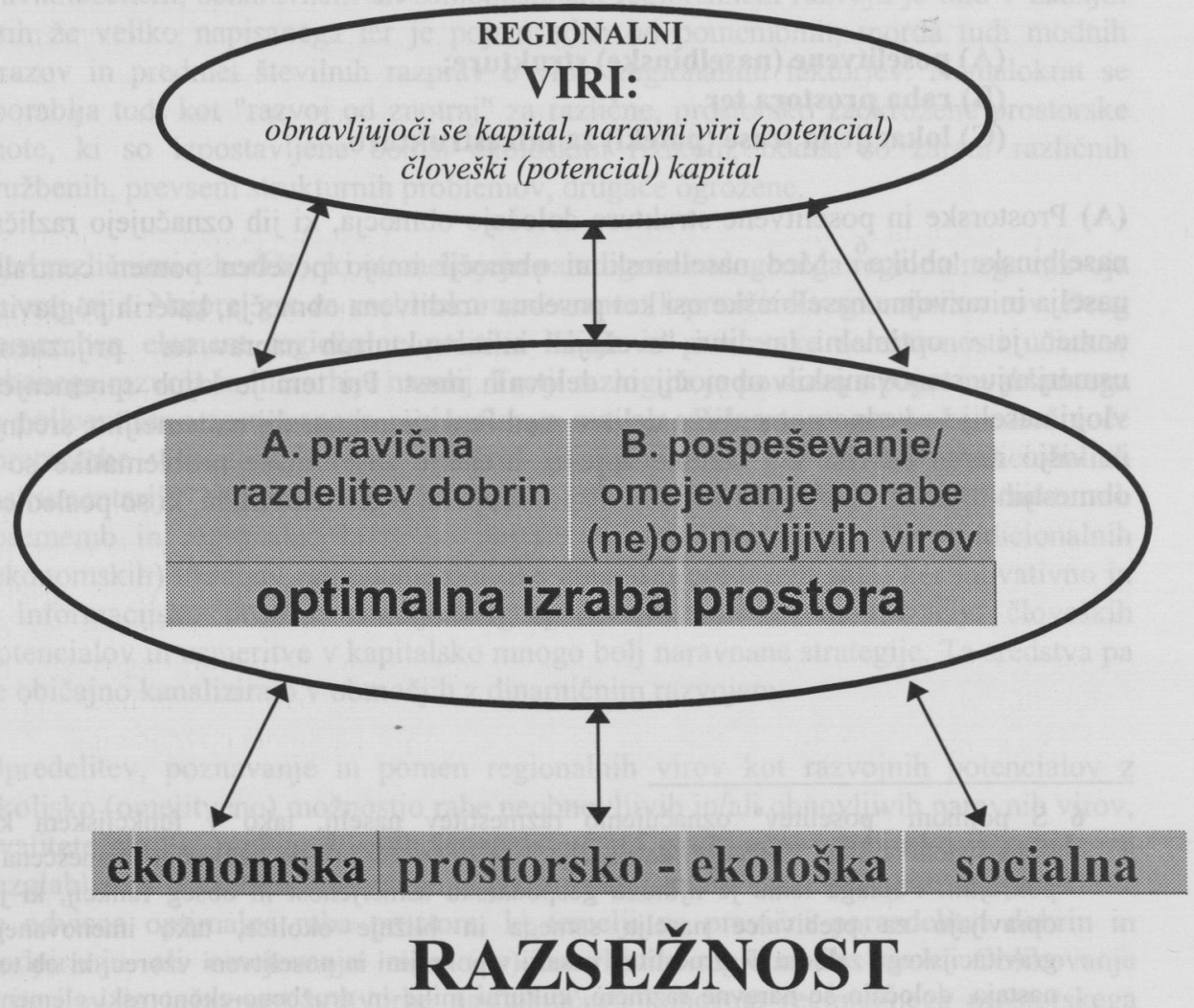


- socialnih sprememb v strukturi prebivalstva,

- ekonomskih sprememb v strukturi prebivalstva,

- morfoloških sprememb v strukturi naselij,

- fiziognomskih sprememb v strukturi naselij in

- sprememb v funkciji objektov.

(B) Določitev namenske rabe prostora se $\mathrm{v}$ regionalnih prostorskih planih praviloma nanaša na vrednotenje rabe zemljišč $\mathrm{v}$ odprtem prostoru. Med njimi razlikujemo zlasti: kmetijske površine, gozdna območja, vodne in obvodne površine (vodno gospodarstvo), stavbna zemljišča, prometne površina, območja rudarjenja, območja za rekreacijo in prosti čas, območja varstva narave... Pri določanju rabe površin je za usklajeno namensko rabo površin običajno nujno potrebno vrednotenje zemljišč na podlagi predhodno določenih kriterijev, ki temelje na različnih vrednostnih stopnjah, npr: varstvena ali prednostna območja za eno izmed zgoraj naštetih dejavnosti.... Prednostna ali varstvena območja namenske rabe imajo pred ostalimi rabami absolutno prioriteto. Kriterijem in določilom optimalne rabe prednostnih območij se morajo prilagajati ostale dejavnosti.

(C) Infrastruktura ${ }^{7}$ ima v regionalnem prostorskem planiranju pomembno vlogo, saj močno vpliva na razvoj naselij in regije nasploh. Infrastruktura je tudi pomemben integracijski dejavnik in omogoča uporabo prostora za različne namene. $\mathrm{Z}$ usklajenim vrednotenjem infrastrukturnih dejavnikov lahko uspešno organiziramo ali urejamo prostor. Še posebej je pomembna za urbana območja, ki brez infrastrukture ne bi mogla delovati. Infrastrukturno omrežje je tudi nadvse pomemben lokacijski dejavnik.

To je po našem mnenju minimalni vsebinski obseg regionalnega prostorskega planiranja, ki ima vgrajene varovalke varovanja skupnih interesov, hkrati pa še vedno dopušča visoko stopnjo svobode $v$ delovanju tržnih mehanizmov. Glede ostalih vsebinskih sestavin je regionalni prostorski plan lahko samo indikativen ali pa reševanje prepušča nižji (občinski) ravni. Zanje se je potrebno dogovoriti na regionalni ravni, pri čemer je potrebno omejiti tudi pristojnosti. Takšna področja so lahko na primer stanovanjska območja, športne površine, parkovne površine ipd.

${ }^{7} \mathrm{~V}$ regionalnem planiranju je dokaj pogosta delitev infrastrukture na:

družbeno (personalno) infrastrukturo: dejavnosti izobraževanja, zdravstva, socialnega varstva, športa/rekreacije, stanovanja , itn.;

gospodarsko (tehnično) infrastrukturo: promet, energetika, komunikacije, obveščanje, tehnična preskrba, komunalna infrastruktura (vodovod, kanalizacija, odlagališča odpadkov);

institucionalno infrastrukturo: splošna uprava, notranja varnost, obramba. 


\section{POMEN IN NALOGE REGIONALNEGA PROSTORSKEGA PLANIRANJA}

Po tradicionalnem razumevanju planerske stroke in planerske prakse je v prostorskem planiranju prav regionalnemu prostorskemu planiranju namenjena osrednja pozornost. Regionalno prostorsko planiranje $\mathrm{z}$ drugimi besedami pomeni smotrno usmerjanje prihodnjega družbenega razvoja v pokrajini (regiji). Regionalno prostorsko planiranje poskuša zato spoznati prostorske zakonitosti in, medsebojne zveze med različnimi dejavniki, raziskati ter na znanstveni podlagi graditi vizijo prihodnjega s prostorskimi elementi vsklajenega družbenega razvoja. Naloge, ki si jih zastavlja regionalno prostorsko planiranje, so nedvomno obsežne in vsestranske in je glede na to skorajda nemogoče pričakovati, da jih bo ta dejavnost lahko naenkrat in docela zadovoljivo razrešila. Zato na regionalno prostorsko planiranje gledamo še, kot na sistem med seboj vsklajenih ukrepov, ki želi družbi $\mathrm{v}$ določeni pokrajini zagotoviti optimalne (ustrezne) možnosti za nadaljnji) razvoj. $\mathrm{Z}$ regionalnim prostorskim planiranjem skušamo preprečiti različne škode $\mathrm{v}$ pokrajini. Zato se metode regionalnega prostorskega planiranja neprestano dopolnjujejo in izboljšujejo $\mathrm{v}$ skladu s potrebami ter s teoretskimi dognanji matičnih in sorodnih znanstvenih disciplin.

Osrednji elementi regionalnega prostorskega plana so nedvomno tisti elementi, ki opredeljujejo dolgoročni razvoj regije in izhajajo iz regionalnih, naravnih, ustvarjenih in prebivalstvenih možnosti. Težišče sodobnega prostorskega planiranja je na reševanju (odpravljanju) prostorskih konfliktov in $\mathrm{v}$ urejanju prostora. To pa sta vsebini, ki sta izvedljivi na mezo in na nižjih ravneh. Zato je regionalni prostorski plan usmerjevalen dokument le na nekaterih ključnih področjih (npr. poselitev, infrastruktura, dediščina...) in/ali območjih, ki imajo v regionalnem merilu poseben pomen (narodni parki, visokogorska območja, obala, območja vodnih virov,itn.) Bistvo tega dokumenta je $v$ jasno definiranih ciljih, razdelanih in konkretiziranih po posameznih področjih. S tega vidika je vsak regionalni prostorski plan naravnan problemsko. Obseg območja tudi naj ne bi bil strogo določen npr. z obsegom območja upravne enote, marveč bi jo narekovala narava problematike:na primer. industrijsko, rudarsko območje, območje s strukturnimi problemi, obmejno območje, ipd.

\section{LITERATURA}

- Aydalot P,. 1986: Milieux innovateurs en Europe. Paris.

- Campagni R., 1991: Innovation networks: Spatial perspectives. London.

- Fromhold-Eisebith M., 1995: Das "Kreative Milieu"als Motorregionalwirtschaftlicher Entwicklung. Forschungstrends und Erfassungsmöglichkeiten. Geographische Zeitschrift, 83, 3-4, Stuttgart, str. 30-66. 
- Handwörterbuch der Raumordnung, 1995: Akademie für Raumforschung undLandesplanung, Hannover.

- Maier J., 1995: Die Grenze als Aktivitäts- und Aktionsräumliches Forschungsobjekt: Verflechstungs- und Beziehungsmuster zwischen Nordbayern und Westböhmen. Neue grenzüberschreitende Regionen im östlichen Mitteleuropa. Frankfurter Wirtschafts- und Sozialgeographische Schriften, Heft 67, str: 91-109, Frankfurt/Main.

- Maillat D., 1992: The Inovation Process and the Role of the Milieu. V. D. Mailat in J. C. Perin (eds): Enterprises innovatrices et development territorial. GREMI. Neuchâtel: EDES, str: 3-20.

- Nijkamp P., Mouwen A. 1987: Knowledge centers, information diffusion and regional development. V: The spatial impact of technological change (eds.: J.H.Brotchie et al.). London, str. 254-270.

- Plut D., 1987: Slovenija - zelena dežela ali pustinja? Ljubljana.

- Rösch A,. 1996: Bisherige Erkenntnisse einer Übertragung in die Regionalentwicklungspolitik. V: Arbeitsmaterialien zur Raumordnung und Raumplanung. Univerzität Bayreuth, Heft 153, Bayreuth, str.101-114.

- Raumplanung in Deutschland, 1995: Eine Einfürung. Bundesministerium für Raumordnung, Bauwesen und Staedtebau, Bonn.

- Ravbar M., 1995: Zasnova poselitve v Sloveniji. Inštitut za geografijo v Ljubljani, Ljubljana, 250 str.

- Ravbar M., 1997: Prispevki za metodologijo regionalnega prostorskega planiranja. Inštitut za geografijo, Ljubljana, delovno gradivo, 81. str.

- Seifert V., 1986: Regionalplanung. Geographische Seminar, Höller und Zwick, Braunschweig.

- Vrišer I., 1978: Regionalno planiranje. Mladinskal knjiga, Ljubljana.

- Walter H., 1983: Wachstums- und Entwicklungstheorie. Stuttgart, New York. 


\section{REFLECTION OF GLOBAL SOCIAL CHANGES IN THE CONTENTS OF REGIONAL SPATIAL PLANNING}

\section{Summary}

In the introductory part, the paper discusses the reflection of global social changes in the contents of regional spatial planning and offers a short overview of the development of spatial planning in the post-War period. The central part of the study is dedicated to the contemporary methodological and contents related views on regional spatial planning and a role of geography in it. Regional spatial planning orders and coordinates the regional use of space in a landscape and its purpose is to make the environment functional, economic, human and esthetic, in which people will have suitable conditions for their dwelling, work and recreation; on the regional level, it performs the tasks assigned by the society for the forthcoming period, and coordinates them with the possibilities and trends, including the landscape effects and results; it transfers the adopted objectives of the socioeconomic policy to the experttechnical level and thus contributes to the spatial organization of society; and finally, it indirectly regulates relations in a landscape, between production, society-made decisions and geographical environment, so as to achieve healthy and organically consistent harmony between the nature and society, which is in favour so of the landscape as of the people living there and, therefore, also protective of natural environment.

Some open questions are also brought up in the paper because the spatial and the regional plannings have to face new challenges and tasks in the current conditions of post-industrial society. The extensive changes in political, economic and the employment structures have been complexly reflected in other social activities (among them also in the spatially relevant ones), too; this, of course, requires the searching of new, more creative contents, methods and instruments for the formation of regional spatial planning, the purpose of which is the consistent regional development. 